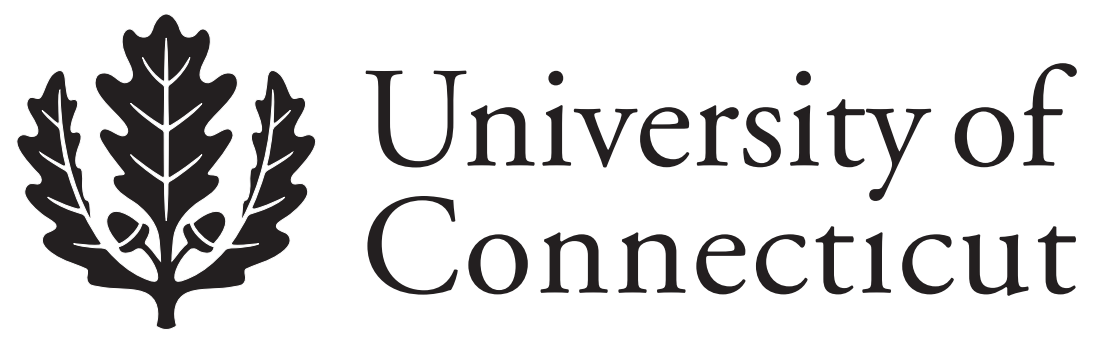

Department of Economics Working Paper Series

Did Impending War in Europe Help Destroy the Gold Bloc in 1936? An Internal Inconsistency Hypothesis

Paul Hallwood

University of Connecticut

Ronald MacDonald

University of Glasgow

Ian Marsh

City University

Working Paper 2007-23

June 2007

341 Mansfield Road, Unit 1063

Storrs, CT 06269-1063

Phone: (860) 486-3022

Fax: (860) 486-4463

http://www.econ.uconn.edu/

This working paper is indexed on RePEc, http://repec.org/ 


\begin{abstract}
This paper investigates the gold bloc operated between France, the Netherlands, Switzerland and Belgium, especially over the period after the USA left the gold standard in March 1933 to its end in September 1936. It enquires into the effect of military-political developments in Germany and Italy on the sustainability of the gold bloc between its members. Juxtaposed is the view of leading political scientists, such as Henry Kissinger, who see impending war in Europe as deeply and adversely affecting psychology in Europe, and what may be called the standard economists view that sees the demise of the gold bloc as being caused almost exclusively by economic factors. Developing concepts of external and internal inconsistency of the gold bloc, this investigation concludes that both economic and military-political developments played important roles in destroying the last vestiges of the gold standard.
\end{abstract}

Journal of Economic Literature Classification: F33, N24, N44

Keywords: French devaluation, German remilitarization, gold bloc, international monetary system 


\section{DID IMPENDING WAR IN EUROPE HELP DESTROY THE GOLD BLOC IN 1936? AN INTERNAL INCONSISTENCY HYPOTHISIS}

We suggest a reinterpretation of the forces that forced France off the gold standard in September 1936. Rather than originating in the purely economic sphere we argue that the reemergence of Germany as a military power is also a likely cause. While it is true that France in the mid-1930s faced a contradiction between reflation of the economy through monetary expansion (to create jobs) and continued adherence to the gold standard; likewise there was a contradiction between increased spending on rearmament (to maintain national security) and maintenance of the gold standard. Moreover, shocks to confidence in a monetary system may originate from outside the purely economic sphere, especially when war with a larger neighbor is in prospect. Indeed, referring to the breakdown of the classical gold standard a generation earlier, Brown (1940) wrote: "During the late spring and early summer of 1914 the shadow of the approaching conflict in Europe was cast over the world's money markets" (page7). And in the period in which we are interested an authority on the history of interest rates writes “throughout the 1930's France struggled unsuccessfully to defend the franc in the face of world-wide depression and the looming prospect of war" (Homer, 1963, page 431. Italics added). We contend that it is legitimate therefore to reopen enquiry into the question of what destroyed the gold bloc - the last vestige of the international gold standard - three years before the outbreak of World War II. In particular, was it only economic forces, or, did the specter of war in Europe play an accompanying role?

In 1925 the international gold standard was reconstituted with its previous major players 
rejoining. As various investigations have shown, it was destroyed in both the UK and the USA by adverse economic and financial circumstances stemming from the Great Depression, and this is also true of Germany (Eichengreen, 1992, Hallwood, MacDonald and Marsh, 1996, 1997 and 2000). As the fourth great player, France, abandoned the gold standard in September 1936, only three-and-one-half years after the USA, earlier investigations of this event have also focused on economic causes (Eichengreen, 1992, Hogg, 1987) ${ }^{1}$. However, we believe that a narrow economic approach to the French suspension misses some important causes as it does not take into account the concurrent transformation of the European military-political order which was hugely to the disadvantage of France.

In this paper we distinguish between the 'external' and the 'internal' inconsistency of the gold bloc regime. ${ }^{2}$ Previous economic analyses of the collapse of the gold bloc has emphasised its external inconsistency. That is, continued adherence to gold rendered the gold bloc countries uncompetitive, with worsening current accounts and falling gold reserves, ultimately they broke under the tension and abandoned gold (see for example, Hautcoeur, 1997). ${ }^{3}$ The internal inconsistency argument presented here is that there was an asymmetric threat from the reemergence of Germany as a military force, and this adversely impacted France more than it did the other gold bloc members. On this assumption, the

\footnotetext{
1 Hogg (1987) concluded: "Having decided to stick to gold, the bourgeois governments of the four countries studied here at the same time refused to face the logical alternative - deflation. This was primarily due to the political factors...in general there was not actual money deflation...Opposition to the continuation of the current parity usually came from isolated academics and sometimes export groups"(Page 208).

${ }^{2}$ The four main members of the gold bloc were Belgium, France, Netherlands and Switzerland. Other original members, Italy, Poland, Danzig and Czechoslovakia all soon moved to foreign exchange controls.

3 Beaudry and Portier (2002), argue that over-valuation of the French franc was not a major factor causing the Great Depression in France because international trade was too small a percentage of GDP (page 86).
} 
gold bloc broke under the strain of gold losses from France, in some measure to other gold bloc countries. Ultimately the French could not sustain these gold losses and abandoned gold. The remaining countries, Switzerland and Netherlands simply followed suit after the bloc's major player had abandoned gold.

We proceed as follows: Section 1 sets out the international military-political context in which the franc was devalued. Section 2 discusses the economic context. Section 3 extends the discussion of the economic context with a statistical investigation of the internal consistency of the gold-bloc's exchange rate regime. We find that exchange rate commitments between the members were not viewed in financial markets as being consistent with one another-implying that the gold bloc was not a credible target zone. An implication of this is that asymmetric shocks stemming from the military-political context were all the more potent. Section 4 discusses how short- and long-term interest rate behavior in the gold bloc-four relates to our thesis of asymmetric military-political shocks playing a role in its destruction. We find some support for the notion that France's commitment to gold was adversely affected by Italy's invasion of Abyssinia, as well as Germany's reoccupation of the Rhineland. Section 5 examines post-gold bloc capital flows. It is pointed out that capital that had left Netherlands and Switzerland in the run up to their abandonment of gold, returned to these countries during 1937 - as it had to Belgium following its devaluation in March-April 1935. However, neither foreign capital nor French capital returned to France during the same year. This set of observations is consistent with the asymmetric military-political shock hypothesis: in financial markets German remilitarization was seen as more of a problem for France than for the other gold bloc 
members. Section 6 concludes.

\section{Section 1: The international military-political context}

The Treaty of Versailles ending the First World War fell far short of satisfying France's national security needs (Kissinger, 1994). In the 1920s, as a counter-weight to Germany the French had wanted a buffer state and alliances, or, border guarantees with the USA and the UK. ${ }^{4}$ But instead of a buffer state the French got only a demilitarized Rhineland (under articles 42 and 43 of the Treaty, reaffirmed by Germany under the Locarno Treaty of 1925); instead of alliances with the major powers, the USA chose what amounted to isolationism, and the British offered only 'diplomatic cooperation' (Kissinger, 1994, p 253). Of this disastrous outcome for French national security, France's victorious military leader, Marshal Foch, famously said of the Treaty of Versailles "This is not peace; it is an armistice for twenty years". ${ }^{5}$

French diplomacy was required to find other national security solutions; none of them, even taken together, turned out to be sufficient. These were collective security through the League of Nations, international guarantee of her borders with Germany (under Locarno), alliances with the new states of Eastern Europe, an attempted alliance with Mussolini's Italy, a political alliance with the Soviet Union and continuing overtures to Britain.

Henry Kissinger writes that France was "in a truly tragic position...it no longer had

\footnotetext{
4 . The Treaty of Guarantee of July 1919 between France, the UK and the USA was not approved in the US Senate and was thereby void.

5 . Quoted by Henry Kissinger (1994), page 250.
} 
confidence in its ability to protect even its own frontiers against a defeated enemy" (1994, page 228). ${ }^{6}$ The influence on the French state of mind was predictable; Kissinger writes of "demoralization" (p 228), of being "obsessively fearful of another round of [German] conquest" (p. 233), of France being a "depleted country" (p. 235), and that France "could not fight another traditional war" (p. 235).

We pick out three foreign military-political developments that could have affected sentiment in France against the franc and to which we refer later. These were

1. March 16, 1935, Germany reintroduces conscription, which was against the Versailles Treaty;

2. October 1935, Italy invades Abyssinia - a foreign policy disaster for France;

3. March 7, 1936, Germany reoccupies the Rhineland, which was against the Versailles Treaty and Locarno Pact, and was a military and another foreign policy disaster for France.

William Shirer writes of the significance of German conscription: "the shackles of Versailles, symbol of Germany's defeat and humiliation, had been torn off" (1959, p. 391). This clearly was an important step in the rise of the Germany's military threat against France.

Mussolini's invasion of Abyssinia in October 1935 was a debacle for French foreign policy. In the vain hope of drawing up an alliance with Italy against Germany, France had acted to thwart League of Nation's sanctions against Italy - imposed because of the latter's invasion. Shirer sums up this failure of French foreign policy: "Because of its hesitations and the devious policies of [Prime Minister] Laval, the French government had lost all: Italy as an

\footnotetext{
${ }^{6}$. For an eyewitness view of French psychology in the 1920s see Shirer (1969, chapter 10).
} 
ally against Germany, the military backing of Russia, Great Britain as a close partner, the League of Nations as a potential force in halting aggression" (Shirer, 1969, p. 250). The upshot was a blow to the ruling, financially orthodox, Radical Party as Premier Laval was forced to resign, and a boost to the leftist the Popular Front.

Most disastrous of all for French security, however, was the German reoccupation of the Rhineland in March 1936. This at once potentially brought German military forces to the French frontier and, by creating a western wall of steel virtually destroyed French foreign policy in Eastern Europe - both because French land forces were blocked and the East Europeans, realizing this, began to look elsewhere for their own security. Of the Rhineland invasion Shirer writes "The whole structure of European peace and security set up in 1919 collapsed" (1969, p 281).

What effect did these foreign policy set backs, occurring within the space of just twelve months, have upon French thinking in the economic and financial spheres? Importantly capital began to flee France. The Bank of France confirmed that outflow of capital from France was largely the result of "large exports of French capital" , April 1936 being an especially bad month. This is the month immediately following German reoccupation of the Rhineland. ${ }^{8}$

\footnotetext{
${ }^{7}$ Annual Report of the Bank of France, page 309 in Federal Reserve Bulletin, April 1937.

${ }^{8}$ The Federal Reserve Bulletin reported that: "At the end of September 1936 short-term balances held by foreigners in the US amounted to $\$ 1,460,000,000$, an increase of nearly $\$ 1,000,000,000$ since the end of 1933. ... French, Dutch and Swiss balances on September $30^{\text {th }}, 1936$, totaled $\$ 390,000,000$, the bulk of which was acquired since the end of 1933. This inward movement of funds was associated to an important degree with financial crises in the gold-bloc countries, though also influenced to some extent by the unsettled international situation in Europe. While readjustment of currencies has been followed by some return of hoarded funds and capital from London, uncertainties abroad continue and gold-bloc balances in the US have been little reduced since September" (Federal Reserve Bulletin, December 1936, page 938).
} 
Paul Einzig (1937) reports a run on the banks in north and north eastern France in March 1936 so linking financial disturbances in France to German military events. Einzig also reports wealthy French streaming across the English Channel to London carrying currency and gold for deposit in British banks which were so swamped that they ran out of safe deposit boxes.

It is possible to argue therefore that military-political developments in Germany and Italy, combined with diplomatic failures to combat them, undermined the confidence of the French not so much in the franc as in the survival of France itself. This is especially so as surely more people than just Pierre Flandin, the Foreign Minister in March 1936, had the prescience to think that "once Germany had fortified the Rhineland, Czechoslovakia would be lost and that, soon after, general war would become unavoidable" (quoted by Kissinger, 1994, page 305).

Military developments in Germany also had clear budgetary implications in France. Einzig (1937) suggests that the French government refused to finance a general mobilization called for by the French military because of its cost. The implication for the budget deficit of the Rhineland reoccupation surely could not have been lost on those people holding liquid capital, for shortly after the new government came to power military spending was indeed increased - by F14 billion (a figure equal to about one-quarter of French gold reserves). ${ }^{9}$

${ }^{9}$. See Shirer (1969) page 308. 
The Dutch central bank in early-1936 made a very clear statement on the adverse budgetary implications of European military-political events:

“The past year [1935] was a period of confusion and contradiction. While it was generally realized in theory that nothing but an improvement of international relations could bring about world recovery, it seemed impossible to put the theory into practice. Political relations showed increasing tension. Lack of confidence and fear of war were felt to an increasing extent. In all countries measures for stronger armaments were adopted. The emergence of storm centers in various parts of the world led even those countries whose peaceful intensions were beyond question to increase their military defenses.

"The resulting heavy demand for raw materials and labor for war industries can hardly be considered a factor of permanent prosperity. Unproductive expenditures of this kind aggravate still further the already heavy burden of Government indebtedness and taxation; even if they are met in the first place wholly or in part out of loan issues, they constitute fresh obligations against the future" (Annual Report of the Netherlands Bank, 1935-36). ${ }^{10}$

Thus, when one considers the international political position of France in the spring of 1936 there is a clear inconsistency between crumbling confidence in national security and a strong franc. This inconsistency should be set side-by-side with the oft stated inconsistency between reflation, say, on the lines of the American New Deal, and a strong franc - an

10 Page 564 in Federal Reserve Bulletin, July 1936). 
argument to which we now turn.

\section{Section 2: Economic factors}

We favor understanding the international gold standard in terms of the monetary approach to the balance of payments (see, e.g., Eichengreen, and Flandreau, 1996, McCloskey and Zecher, 1976, Dornbusch, 1973, or Johnson and Frenkel, 1976). This analysis is implicit in Eichengreen's (1992) authoritative economic study of the gold bloc. In this view monetary dis-hoarding and balance and payments deficits are occasioned by excessive rates of domestic credit expansion. The main problem for the French following the devaluations of the pound and dollar in, respectively, September 1931 and March 1933, was that higher prices in the sterling and dollar areas encouraged hoarding in these which, evidently, was not matched by sufficient domestic credit expansion as gold flowed to them through balance of payments surpluses from the gold bloc countries.

As the gold bloc countries had ruled out foreign exchange controls, payments equilibrium could be restored only under one (or a combination) of two circumstances. Either their price levels had to fall sufficiently to cheapen their exports so much as to end the desire to hoard in the sterling and dollar areas; or the gold bloc countries ended the international price level disparity by themselves devaluing - so ending their desire to dis-hoard. However, all leading political parties in France were set against devaluation - mainly because of the fear that it would lead to a repeat of the inflation suffered in the 1920s.

Unfortunately, the process of price-deflation in the gold bloc-four was drawn out and at a 
huge cost in terms of unemployment. ${ }^{11}$ The Bank of France staunchly defended the franc with tight money. Indeed, from 1931 the French real money base increased least among the four gold bloc countries. Successive deflationary packages were implemented (the last of them in July and November 1935). However, resistance to deflation grew, and the fall of the Laval government in January 1936 - as mentioned above over foreign policy issues, marked the end of French tolerance of deflationary policies.

What of a policy of reflation instead of deflation? Under French monetary conditions - a small government bond market and commercial banks already stuffed with Treasury bills, increased government spending required monetization. But the latter also ran into the logic of money in an open economy: excessive domestic credit expansion would weaken the balance of payments and serve further to reduce already dwindling gold and foreign exchange reserves.

With French public wearied of the Depression but still set against devaluation they increasingly turned to the Popular Front which stood for the contradictory policy of reflation without devaluation (Eichengreen, 1992). With unemployment so high one may wonder why the French public was so resolved against devaluation. Shepherd explains that "in continental Europe, the distinction is seldom drawn in the popular mind between devaluation and inflation" (1936, page 199). The Popular Front's prospective and actual victory in the General Election of April/May 1936 set the stage for a run on the franc which lasted from March to September (with only with an interruption in July). But, it

\footnotetext{
${ }^{11}$ See Eichengreen (1992) chapter 12 for a description of the prolonged Depression in France.
} 
should be noted, the supposed effects of the Popular Front are confounded with the asymmetric military-political shock hypothesis put forward here.

\section{Section III: Exchange Rate Behavior}

We begin our analysis of the gold bloc and its collapse with a consideration of how soundly the four members were viewed in financial markets as being wedded to the gold standard. If a country is thought by financial markets to be securely tied to gold its exchange rate should be mean reverting (Krugman, 1991, Bertola and Svensson, 1993). That is, if an exchange rate is near either of the gold points, especially the gold export point where the currency is weak, it should tend to revert toward the center of the band, rather than to bump along one of its edges. To test for mean reversion of gold bloc exchange rates we use the variance ratio test, originally proposed in the economics literature by Cochrane (1988) and previously used to test for mean reversion of exchange rates under the classical gold standard by Hallwood, MacDonald and Marsh, $1996 .{ }^{12}$

The variance ratio test is potentially a powerful way of testing for the univariate meanreverting properties of a series because it can capture potential long autocorrelations which are unlikely to be captured in standard Dickey Fuller type tests, and which can be important in producing mean reversion. Under the null hypothesis that a variable, such as the exchange rate, follows a random walk, the variance of the kth difference should equal $\mathrm{k}$ times the first difference. That is,

$$
\operatorname{Var}\left(q_{t}-q_{t-k}\right)=k \operatorname{Var}\left(q_{t}-q_{t-1}\right) .
$$

On rearranging this expression we have:

\footnotetext{
${ }^{12}$ Exchange rate data abstracted from Board of Governors of the Federal Reserve System (1943), Banking and Monetary Statistics, Washington DC.
} 


$$
V_{k}=(1 / k) \cdot\left[\left(\operatorname{Var}\left(q_{t}-q_{t-k}\right)\right) \cdot\left(\operatorname{Var}\left(q_{t}-q_{t-1}\right)\right)^{-1}\right]=1
$$

where $V_{k}$ denotes the variance ratio, based on lag $\mathrm{k}$. So a finding that an estimated value of $V_{k}$ equals unity would imply that the exchange rate follows a random walk. However, if $V_{k}$ turns out to be less than unity this would imply that the exchange rate was stationary and mean-reverting. The intuition for this is straightforward - if the underlying process driving the real exchange rate is mean- reverting, the variance of the series would decrease as $\mathrm{k}$ becomes larger. Alternatively, if $V_{k}$ turns out to be greater than one, the exchange rate would exhibit 'super-persistence'

For the Classical and inter-war gold standard periods, exchange rates do appear to be strongly mean-reverting, thereby supporting the view that these gold standard episodes were credible (see, for example, Hallwood MacDonald and Marsh (1996) and secure on gold.

The results of our variance ratio test for the gold bloc period are reported in Table 1, for lag lengths $\mathrm{k}=2$ through to $\mathrm{K}=30$. In sum, and in contrast to the results reported for other gold standard periods, the results here show no sign of exchange rate mean reversion for any of the four currencies against each other. The results are read in the following way. For each currency we present two variants of the variance ratio test $-\mathrm{V} 1$ and V2. The former is calculated using a small sample correction, which is likely to be important in the current application, whereas the latter is not. The column headings $K=2$ to $K=30$ denote the lag lengths (number of months) used to calculate the variance ratio test. Numbers in parenthesis denote the standard error. The results are unambiguous since all apart from one cell entry (V2 and $\mathrm{K}=30$ for the Belgian franc) exhibit super persistence 
and an absence of mean reversion. As we have said these results are very different to other gold standard experiences and we conclude from this that

\begin{tabular}{|l|l|l|l|l|}
\hline \multicolumn{5}{|l|}{ Table 1: Variance ratio test for mean reversion of gold bloc exchange rates } \\
\hline Lag Length & $\mathrm{K}=2$ & $\mathrm{~K}=5$ & $\mathrm{~K}=10$ & $\mathrm{~K}=30$ \\
\hline Currency & & & & \\
\hline $\begin{array}{l}\text { V1 Be } \\
\text { Franc }\end{array}$ & 1.73 & 3.21 & 4.48 & 2.57 \\
\hline $\begin{array}{l}\text { V2 Be } \\
\text { Franc }\end{array}$ & 1.52 & $(0.00)$ & $(0.00)$ & $(0.01)$ \\
\hline $\begin{array}{l}\text { V1 Fr } \\
\text { Franc }\end{array}$ & 1.88 & 1.81 & 3.37 & 0.63 \\
\hline $\begin{array}{l}\text { V2 Fr } \\
\text { Franc }\end{array}$ & 1.69 & 1.41 & 2.23 & $(0.52)$ \\
\hline & $(0.09)$ & $(0.16)$ & $(0.15)$ & $(0.18)$ \\
\hline $\begin{array}{l}\text { V1 Sw } \\
\text { Franc }\end{array}$ & 1.68 & 1.59 & 1.24 & 3.50 \\
\hline & $(0.09)$ & $(0.11)$ & $(0.21)$ & $(0.00)$ \\
\hline $\begin{array}{l}\text { V2 Sw } \\
\text { Franc }\end{array}$ & 1.52 & 1.24 & 1.95 & 1.15 \\
\hline
\end{tabular}




\begin{tabular}{|l|l|l|l|l|}
\hline & $(0.13)$ & $(0.21)$ & $(0.05)$ & $(0.25)$ \\
\hline $\begin{array}{l}\text { V1 Ne } \\
\text { Guilder }\end{array}$ & 1.52 & 2.09 & 2.72 & 4.08 \\
\hline & $(0.13)$ & $(0.04)$ & $(0.01)$ & $(0.00)$ \\
\hline $\begin{array}{l}\text { V2 Ne } \\
\text { Guilder }\end{array}$ & 1.80 & 1.79 & 2.09 & 1.88 \\
\hline & $(0.07)$ & $(0.07)$ & $(0.04)$ & $(0.06)$ \\
\hline
\end{tabular}

Notes: V1 Denotes the variance ratio calculated with a finite sample correction and V2 is the corresponding ratio without such a correction (see Wright, 2000). Numbers in parenthesis are heteroscedasticty robust $\mathrm{p}$-values.

the gold bloc was never securely based on gold. It was, therefore, vulnerable to both external inconsistency of price levels with its trade partners/rivals and to asymmetric military-political shocks originating in Germany and Italy. That is, this analysis supports both the external inconsistency argument of, inter alia, Eichengreen (1992), and our internal inconsistency hypothesis. Interestingly, Ritschl and Wolf (2003) throw some light as to why gold bloc countries' cross exchange rates were not strongly mean reverting. Their evidence is that the gold bloc members were not particularly well tradeintegrated with each other. Specifically, that 1928 trade patterns did not 'predict' membership of the gold bloc, while they did so for the Reichsmark bloc and the sterling bloc which were both formed after sterling was knocked off gold in September 1931. We move on to see whether internal inconsistency was indeed a factor in causing the collapse of the gold bloc.

\section{Section 4: Interest rates}

We use Switzerland as a 'base' country as it was much less likely to become embroiled in a new world war than was France. Indeed, "Switzerland enjoyed unusual political and economic stability for almost a century and a half. Beleaguered but untouched by two world wars, the small nation became a symbol of neutrality and a safe haven for refugee 
capital" (Homer, 1963, page 470). Thus, we assume that changes in French interest rates relative to Swiss rates captures at least some of the asymmetric shock of German remilitarization on the internal coherence of the gold bloc

Using 12 month moving averages it cannot be said for the period 1928(11) to 1936(12) that there is a "normal" level of short-French interest rates - at least as measured by the available data, which is for private discount rates. ${ }^{13}$ They were high at the beginning of the period, reflecting French franc weakness soon after (de facto) rejoining the gold standard - something that is supported by the revelation of strong devaluation expectations against the French franc held in foreign exchange markets as shown in Hallwood, MacDonald and Marsh (1996). French interest rates fell back in the middle months of our data period as foreign exchange speculation moved first against the pound sterling - pushing it off gold in September 1931 - followed by speculation against the US dollar, which fell in March 1933 (see Hallwood, MacDonald and Marsh, 1997, 2000). However, French short-term interest rates climbed sharply from spring 1935 - concurre nt with the Belgian banking crisis and the severely deteriorating international political situation discussed above. They remained high thereafter.

To pick out the effect of military-political events on the internal consistency of the gold bloc we turn to a discussion of:

a) Behavior of short-term interest rates of other gold bloc countries against France. From the theory of uncovered interest rate parity, a rise in French short term interest rates relative to those of another member indicates expected depreciation of the French franc.

\footnotetext{
${ }^{13}$ Short term interest rate data for France, the Netherlands and Switzerland collected from the Board of Governors of the Federal Reserve System (1943), Banking and Monetary Statistics, Washington DC.
} 
b) Yield gap analysis - a rise in short term rates relative to long rates generally indicates worsening economic conditions ${ }^{14}$.

\section{a) Short-term interest rates in the gold bloc}

Figure 1 shows the short-term interest rate spread (private discount rates). Negative values indicate higher French short-term rates. The figure shows quite convincingly that French short-term interest rates rose sharply compared with those of Belgium and Switzerland in the second quarter of 1935 shortly following Germany's reintroduction of conscription in the March of that year. French short-term rates where to remain higher than those of the other countries through to the end of the gold bloc in September 1936.Also shown is that the interest rate differential moved even more sharply against France in the fourth quarter of 1935 - at the time of Italy's invasion of Abyssinia; and again in the second quarter of 1936, following Germany's reoccupation of the Rhineland in March. Indeed, the Federal Reserve (Bulletin, July 1936) explicitly linked short-term capital flows to the US with the Abyssinian situation. ${ }^{15}$

\footnotetext{
${ }^{14}$ France: long bond, 3 percent irredeemable government bond; the Netherlands: $2.5-3$ percent irredeemable government bond; Switzerland: State and Federal 3.5 percent railways bond. Data collected from League of Nations Statistical Yearbook, various issues.

${ }^{15}$ Thus, "When the tension in Europe over the Ethiopian situation reached a critical point last autumn [1935], there was a heavy transfer of funds from London to New York, and other times international political developments abroad appear to have stimulated the flow of capital", (Federal Reserve Bulletin, July, 1936, page 511). The Swiss National Bank in its Annual Report for 1935 also linked the Abyssinian situation with interest rate developments. Thus, "Economic sanctions decreed by the League of Nations against Italy and made effective on November $18^{\text {th }}, 1935$, created a new barrier to international trade" (Annual Report reprinted in Federal Reserve Bulletin, May 1935, page 344). These last two quotations from central bank reports make a clear link between the Abyssinia invasion, constrained international trade, and speculation against the French franc - occurring in the same month as the League of Nations sanctions
} 


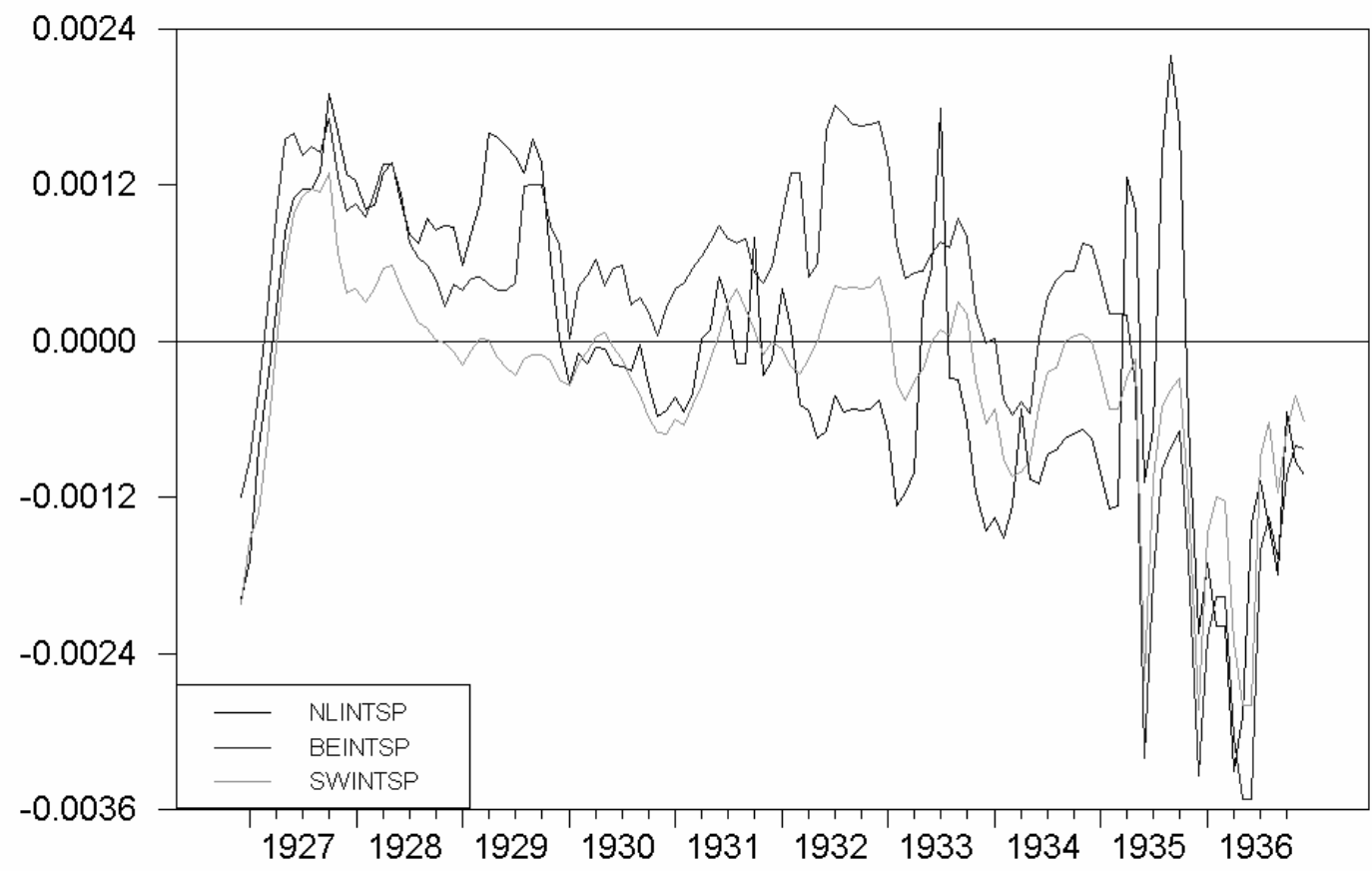

Figure 1: Short-term interest rate (private discount rates) spreads of Netherlands, Belgium and Switzerland compared with France

\section{b) Yield gaps}

One way to indicate the effect of German remilitarization on the internal consistency of the gold bloc is to compare French and Swiss interest rate gaps (long- minus shortrates $)^{16}$. A rise in the short-term interest rate relative to the long rate is often taken as a sign of economic and/or financial weakness (Mishkin, 1995, and references there in, Dotsey, 1998). Under a pegged exchange rate regime such as the gold standard, a rise in short-term interest rates indicates a lack of trust in the stability of the value in foreign currency of short-dated securities. Lower interest rates on long-term securities, or, at least a rise in short rates relative to long rates, may indicate the expectation of a long-term

\footnotetext{
${ }^{16}$ French yield curve: $3 \%$ irredeemable government bonds minus one month private discount rate. Swiss yield curve: $3.5 \%$ federal and state railway bonds less one month private discount rate. Source: League of Nations, various issues.
} 
weakening in the real economy. Mishkin (1995, page 16), using data for five countries, ${ }^{17}$ finds positive relationships between changes in the yield curve and future rates of real economic activity. That is, a steeper yield curve is associated with increased levels of economic activity, and a flattening of it with reduced activity. In particular, a yield curve flattening may occur with a combination of a rise in short-term interest rates and a negative shock to expected real economic activity. ${ }^{18}$ We argue that military-political shocks (emanating from Germany) on France would indeed cause short-term interest rates to rise relative to long-rates. In 1936 French short-term interest rates did rise - to stem a capital outflow, while it is arguable that prospects for the French real economy would also have been adversely affected.

Of interest therefore is how the French yield gap (French long-rate minus French shortrate) behaved relative to the comparable Swiss yield gap (Swiss long-rate minus Swiss short-rate). Switzerland is taken as the "base" country because our interest is in how military-political events in Europe in the months from March 1935 to the abandonment of the gold standard by the French in September 1936, may have impacted French financial markets. As explained earlier, Switzerland is used as the base country on the assumption that its financial markets would have been less concerned with events across the border in Germany, than investors would have been in France. Simply, Switzerland was much less affected than was France by German military and political events, and nor did Switzerland face a foreign policy debacle - as France did when Italy invaded Abyssinia. This is our asymmetric military-political threat hypothesis.

\footnotetext{
${ }^{17}$ The five countries are France, Italy, Germany, the UK and the USA. The data period is 1973-1994.

${ }^{18}$ The effect on real interests of an adverse shock to expected real economy activity can be simply modeled as a leftward shift in the IS curve in ISLM space.
} 
Figure 2 shows time series of French-Swiss short-term and long-term interest rate differentials. It is apparent that from about late-1934 and especially spring 1935, that French short-term interest rates rose relative to $\mathrm{S}$ wiss rates, while at the same time French long-term interest rates fell relative to Swiss long-term rates.

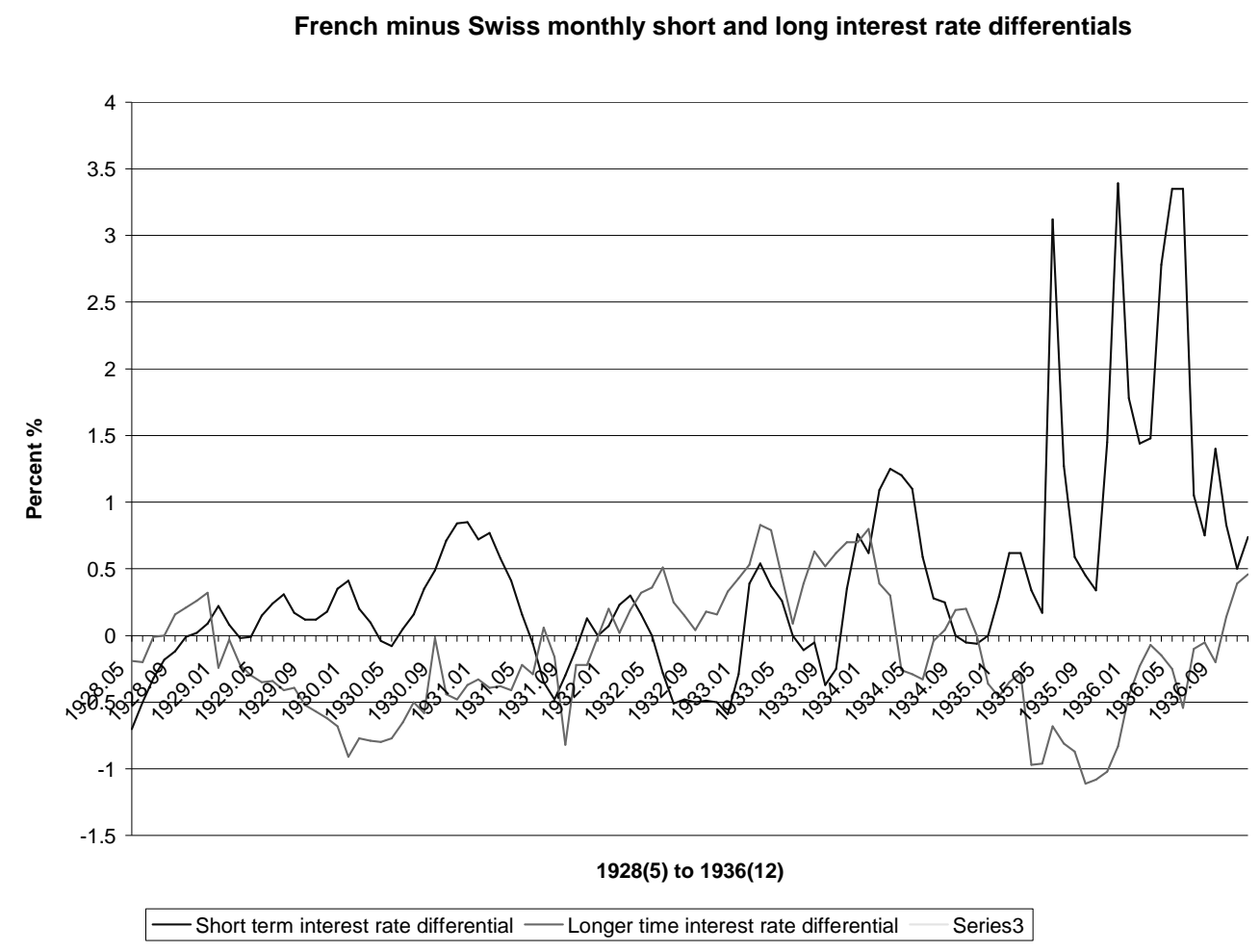

Figure 2: French minus Swiss monthly short- and long-term interest rate differentials

Clearly, at this time there were significant changes in the French and Swiss yield curves.

Figure 3 indicates the extent of the relative shifts in yield curves. ${ }^{19}$

${ }^{19}$ The time series in figure 3 is calculated using the following interest rates

(French long - French short) - (Swiss long - Swiss short) 
FRENCH YIELD CURVE MINUS SWISS YIELD CURVE

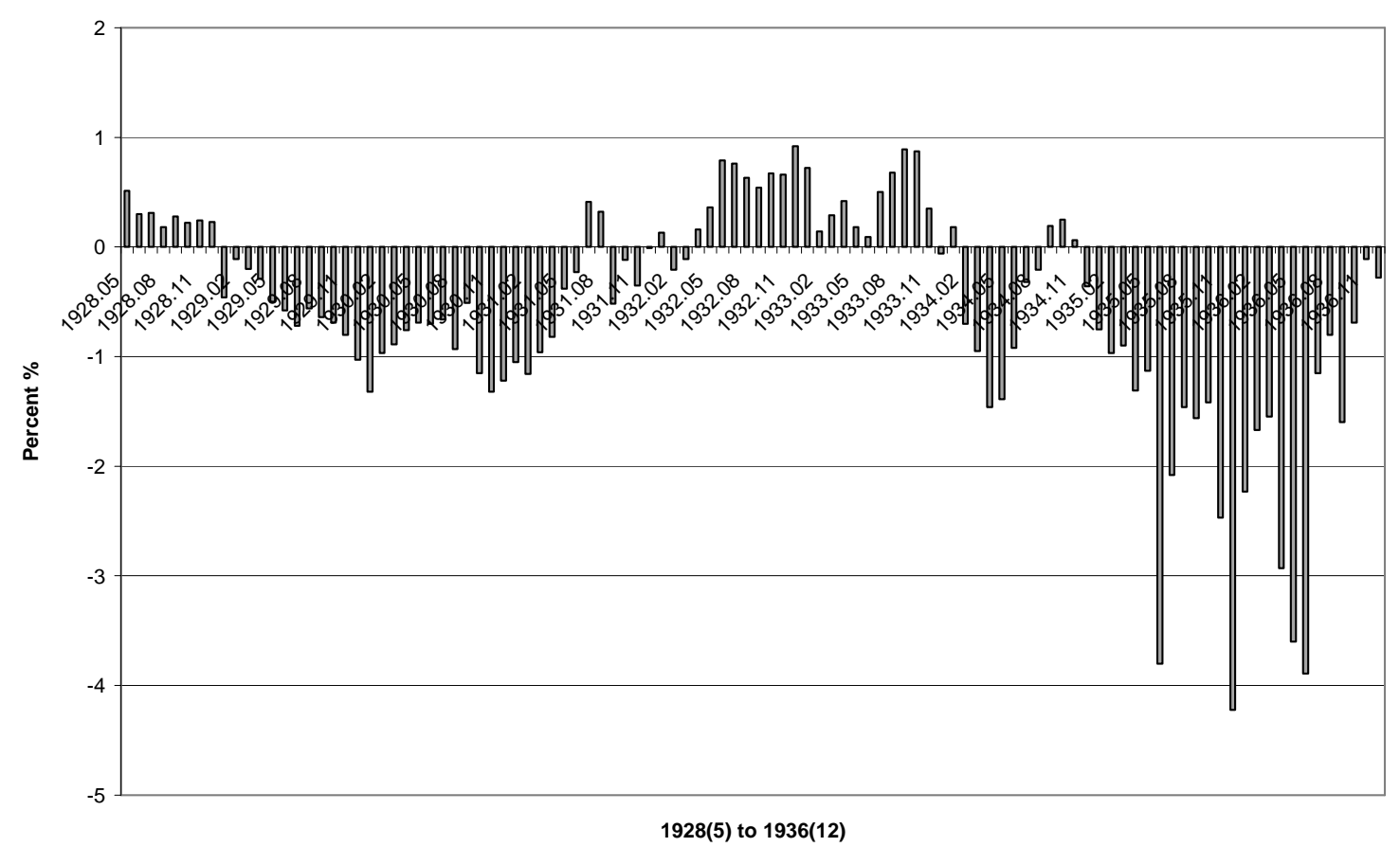

Figure 3: French yield gap minus Swiss yield gap: 1928(5) to 1936 (12)

From November 1930 to June 1932 the French yield gap was steeper than the Swiss (positive segment of figure 3), and this may be taken to indicate relatively good economic conditions in France. However, the yield gap difference turns negative in August 1933 and was to remain so to the end of our data period in December 1936, as French short rates rose relative to Swiss short rates, and French relative long rates moved downwards.

What interpretation can be put on the behavior of the respective yield gaps? The time series in figure 3 fluctuated between positive and negative from the beginning of our data period in May 1928 to November 1934, but the differences in the respective yield gaps are never so large as in the period concurrent will military-political events in Germany. 
Beginning in December 1934 the yield curve inversion moves more strongly negative than it had done before. This last decisive yield curve inversion indicates weakness in French financial markets and real economy relative to Swiss. Thus, the relative rise in the French short rate (figure 4) indicates a lack of trust in French short-term assets. The contemporaneous French long rate falling relative to Swiss long rate can be taken as a sign of expected weakness in the French real economy - French long rates falling because the real sector is reducing its borrowing and spending (relative to the Swiss). On this interpretation, from early-1935 onward French short-term markets were weakening relative to Swiss while the French real economy was expected to weaken (again relative to the Swiss).

What was the cause of the inversion of the relative yield gap? As we noted in the previous section, Germany introduced conscription in March 1935 and reoccupied the Rhineland a year later. All of this aimed at France, with Switzerland remaining a safe haven. This is the internal inconsistency interpretation of what caused the gold bloc to end in September 1936 is different compared with the standard external inconsistency argument - that the members were fed up with the depression that they were bringing on themselves. We don't doubt the external inconsistency argument but we do think that we have established that internal inconsistency problems were also causal factors.

The yield gap picture is similar when comparing France and the Netherlands. Thus, figure 4 shows French minus Dutch short and long interest differentials from 1933(3) to 
1936(12). ${ }^{20}$ And Figure 5 shows the French yield gap minus that of the Netherlands. The relative flattening of the French yield gap, in this case from November 1935, is again apparent.

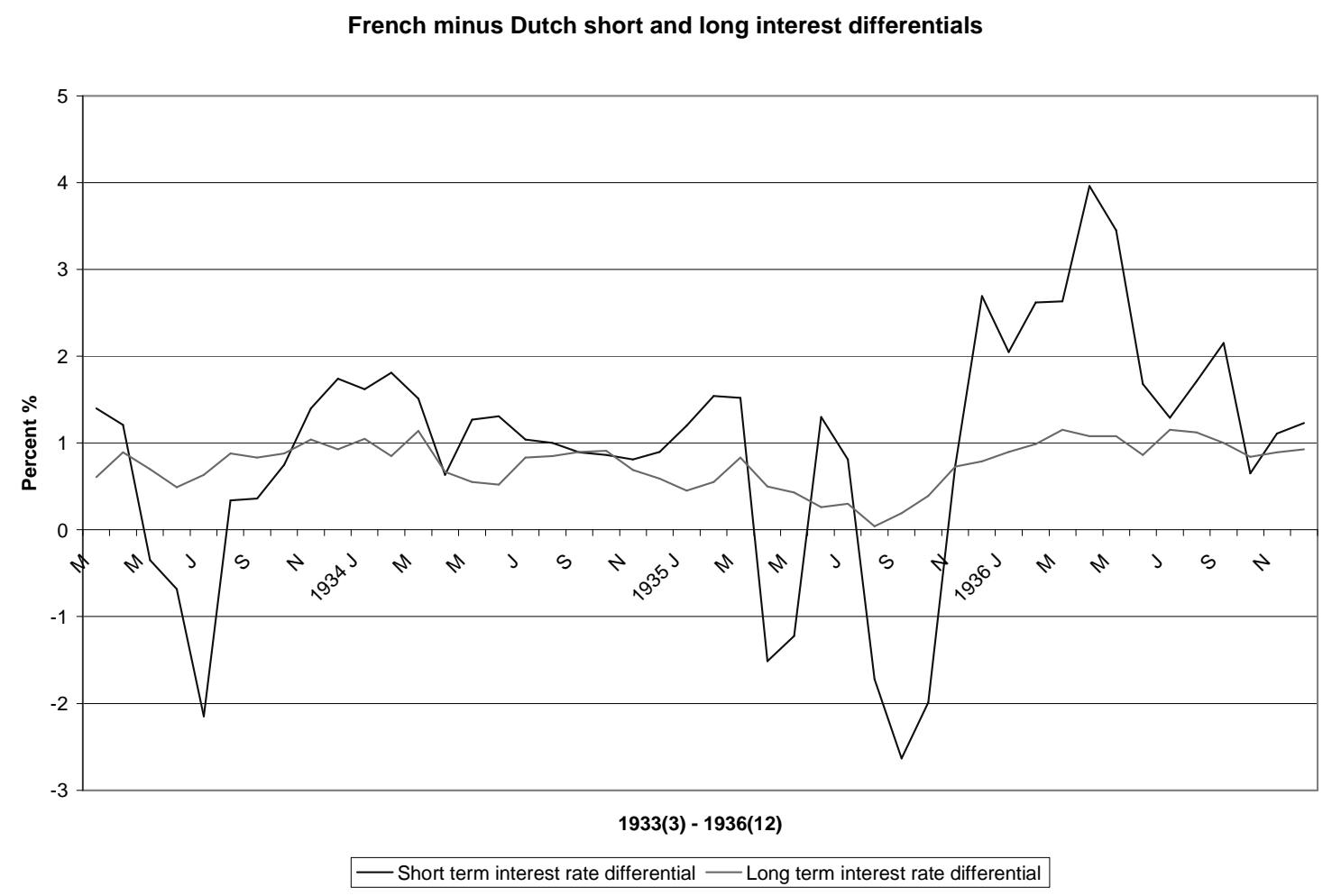

Figure 4: French minus Dutch short-and long-term interest rate differentials

\footnotetext{
${ }^{20}$ The shorter period for Dutch data compared with that of France or Switzerland is due to the Netherland Bank temporarily publishing relevant interest rate data quarterly rather than monthly in the middle of our data period. The French interest rate data is as defined above. That of the Netherlands is the private discount rate as proxying for Dutch short-term interest rates, and government 2.5\%-3\% irredeemable bonds for long-rates.
} 


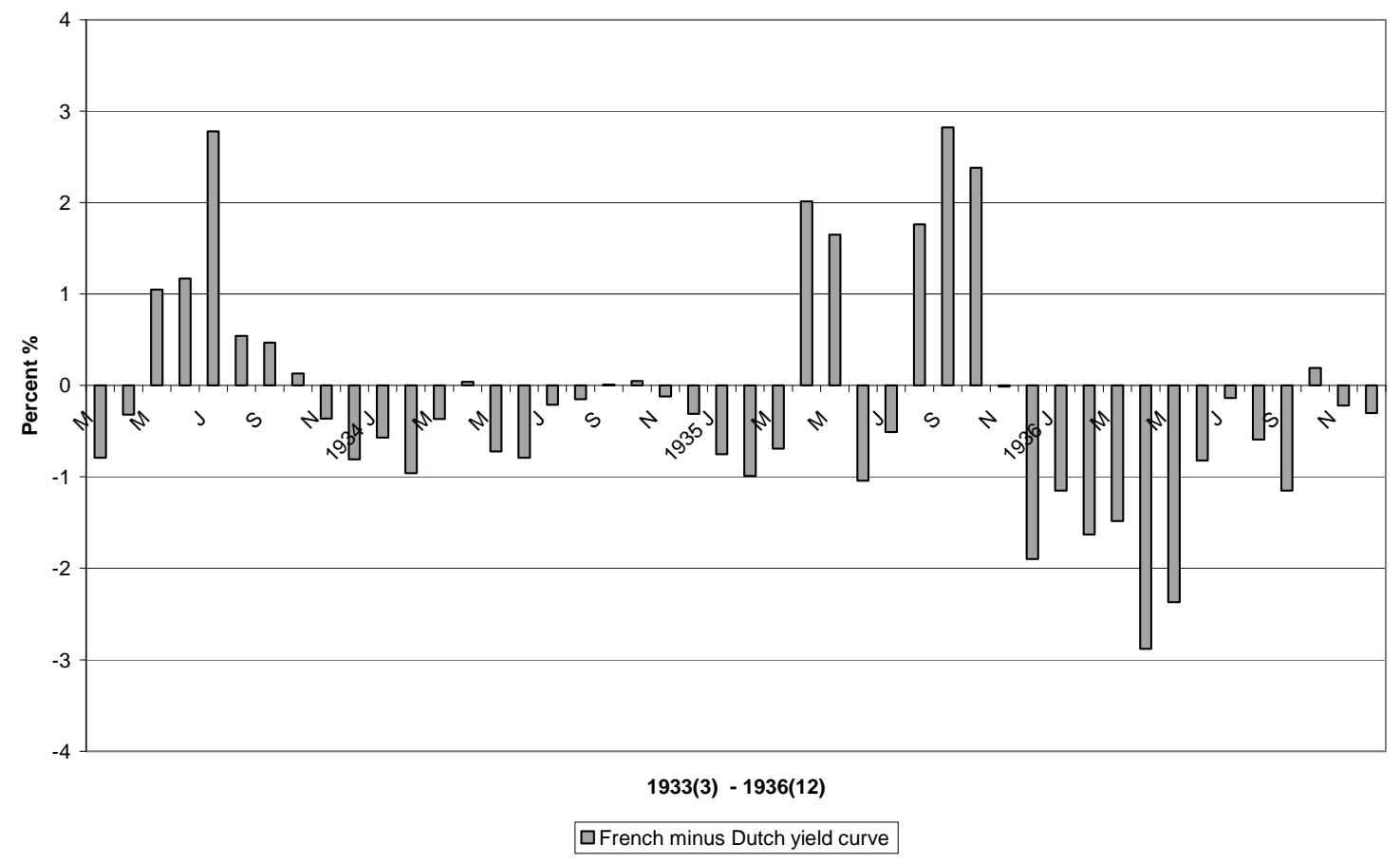

Figure 5: French yield gap minus Swiss yield gap: 1933(3) to 1936(12)

Section 5: Post devaluation capital flows

Following the currency devaluations of September 1936 and the tripartite agreement to stabilize the foreign exchanges between France, the UK and the US (in short order joined by Switzerland, Netherlands and Belgium), it can be argued that capital outflows from the former gold bloc members would reverse themselves as investors repatriated capital from abroad in order to take their profits. However, if German remilitarization was a factor alarming wealth holders in equal measure in each of the gold bloc members, it is entirely possible that capital placed abroad would not return. In fact, in the final quarter of 1936, the international bullion and specie balances of the Netherlands and Switzerland (as well as Belgium which had re-pegged to gold following its devaluation of March- 
April 1935) were in surplus as flight capital began to be repatriated to these countries (League of Nations, various issues) ${ }^{21}$. However, the bullion and specie balance of France remained strongly negative, signifying that net capital outflow continued despite the French devaluation. The juxtaposition of the behavior of these capital flows lends further support to the hypothesis that German remilitarization did indeed have an asymmetric effect on the gold bloc members, with, as hypothesized, France being the more adversely affected.

Comments at about this time in central bank annual reports also support the asymmetric military-political shock hypothesis. Thus, the Federal Reserve Bulletin for December 1936 noted that following currency devaluations by the former gold bloc countries in September of that year that "uncertainties abroad continue and gold bloc balances in the United States have been little reduced since September" (Bulletin, December page 938). What gold did return was primarily from London. Uncertainties in France were more severe than in the other former gold bloc countries because, as the Annual Report of the Netherlands Bank, 1937-38, noted, France was the only one of the six main gold-holding countries to lose monetary gold during $1937 .^{22}$ The other former gold bloc countries, Netherlands, Switzerland and Belgium, all gained gold that year. The value of gold held by the Netherland Bank increasing enormously, by 59 percent, in the year to March $31^{\text {st }}$, 1938 (page 663) ${ }^{23}$. Moreover, so strong was the flow of funds to Switzerland in 1937 ,

\footnotetext{
${ }^{21}$ Following the devaluation of the Swiss Franc on $27^{\text {th }}$ September 1936, the Swiss National Bank reported that "large amounts of Swiss and foreign gold coins..., as well as gold bullion reappeared at the window of the Bank" (Annual Report, 1936, page 321 in Federal Reserve Bulletin, April 1937).

22 The six main holders of gold at end-1937 with 82 percent of the world's monetary gold stock were the US, the UK, France, Netherlands, Switzerland and Belgium (Netherland Bank, page 659).

${ }^{23}$ Page numbers in this paragraph are those in Federal Reserve Bulletin, August 1938.
} 
threatening both exchange rate and price level stability, that the Swiss National Bank established a "Gentlemen's Agreement" with Swiss banks to reduce the "excessive volume of foreign deposits held by the banks in Swiss currency" (Swiss National Bank, Annual Report). ${ }^{24}$ As to France, the Netherland Bank Annual Report, 1937-38, said that "permanent restoration of confidence in the financial and monetary position of France, with a consequent repatriation of French capital and a return flow of gold to France" was yet to occur (page 659).

\section{Section 6: Conclusions}

We distinguish two different causes of the abandonment of gold by the gold bloc members (France, Netherlands and Switzerland) in September 1936 - the external and internal inconsistency hypotheses. The external inconsistency hypothesis, extant in the literature, takes the form of an argument that economic causes - high price levels in the gold bloc relative to non-gold bloc countries (such as the US and the UK) exerted deflationary pressures in the gold bloc that eventually became intolerable. In this paper we have put forward an alternative internal inconsistency hypothesis - that the gold bloc became unworkable because of asymmetric military-political shocks emanating from Germany and Italy adversely affecting confidence in the French franc to a greater extent than either the Swiss franc or the Dutch gilder.

We find some support for this internal inconsistency hypothesis. In particular we show

24 Page 362 in Federal Reserve Bulletin, May 1938. 
that short-term interest rates rose in France relative to Netherlands, Switzerland and Belgium concurrent with military-political events in Germany. Moreover, at the same time, we find that the French yield curve flattened relative to those of both Switzerland and the Netherlands - events that we interpret as showing both (relative) declining confidence in the French franc and (relative) worsening expected long-run economic conditions in France. However, the available data does not allow a researcher to claim that either the internal or external inconsistency hypothesis dominates. Indeed, our variance ratio test, indicating a lack of mean reversion in gold bloc currencies something that is inconsistent with systems of pegged exchange rates that are thought in financial markets to be secure, lends support to both hypotheses. Thus, we conclude that the internal and external inconsistency hypotheses are complementary, and that it would be wrong to argue for either one excluding the other. 
References

Bertola, G. and Svensson, L.E.O. (1993), "Stochastic Devaluation Risk and the Empirical Fit of Target-Zone Models, Review of Economic Studies, 60, 689-712.

Brown, W.A. (1940), The International Gold Standard Reinterpreted, 1914-1934, AMS Press, New York.

Beaudry, P. and Portier, F. (2002), "The French Depression in the 1930s", Review of Economic Dynamics, 5, 73-99.

Cochrane, J.H. (1988) How Big Is the Random Walk in GNP? The Journal of Political Economy, Vol. 96, No. 5, 893-920. Oct., 1988.

Dornbusch, R. (1973), "Devaluation and Nontraded Goods, American Economic Review, 63, 871-80.

Dotsey, M. (1998), “The Predictive Content of the Interest Rate Term Spread for Future Economic Growth", Federal Reserve Bank of Richmond, Economic Quarterly, 84 (3), Summer, 31-51.

Eichengreen B. (1992), Golden Fetters, Oxford University Press, Oxford.

Eichengreen, B. and Flandreau, M. (1996), "Blocs Zones, and Bands: International Monetary History in Light of Recent Theoretical Developments", Scottish Journal of Political Economy, 43 (4), 398-414.

Einzig, P. (1937), World Finance 1935 - 1937, MacMillan, New York.

Griffiths, R.T. (editor) (1987), The Netherlands and the Gold Standard, 1931-36, Neha, Amsterdam.

Hallwood, P., MacDonald, R. and Marsh, I. (2000),"An Assessment of the Causes of the Abandonment of the Gold Standard by the USA in 1933", Southern Economic Journal, 67 (2), October, 448-459.

Hallwood, P., MacDonald, R. and Marsh, I, (1997) "Crash! Expectational Aspects of the UK's and the USA's Departures from the Inter-War Gold Standard", Explorations in Economic History, 34, 174-194.

Hallwood, P., MacDonald, R. and Marsh, I. (1996), "Credibility and Fundamentals: Were the Classical and Inter-War Gold Standards Well-Behaved Target Zones?" in Modern Perspectives on the Gold Standard, (edited by T. Bayoumi, B. Eichengreen, and M.P. Taylor), Cambridge University Press, Cambridge, England,.

Hautcoeur, P. (1997), “The Great Depression in France (1929-1938)”, in D. Glasner, ed., Business Cylces and Depressions: An Encyclopedia, Garland, New York

Hogg, R.L. (1987), "Belgium, France, Switzerland and the End of the Gold Standard", chapter 9 in R.T. Griffiths, op. cit. pp

Homer, S. (1963), A History of Interest Rates, Rutgers University Press, New Jersey.

Johnson, H.G. and Frenkel, J.A. (1976), The Monetary Approach to the Balance of Payments, Allen and Unwin, London.

Kissinger, H. (1994), Diplomacy, Simon and Schuster, New York.

Krugman, P. (1991), "Target Zones and Exchange Rate Dynamics", Quarterly Journal of Economics, 8, 445-56.

League of Nations, Monthly Bulletin of Statistics, various issues.

McCloskey, D.N. and Zecher, J.R. (1976), "How the International Gold Standard Worked, 1880-1913", In J. A. Frenkel and H.G. Johnson (eds), The Monetary Approach to the Balance of Payments, University of Toronto Press, Toronto, 357-85. 
Mishkin, F.S. (1995), "The Term Structure of Interest Rates and its Role in Monetary Policy for the European Central Bank", NBER, Working Paper 5279.

Ritschl, A. and Wolf, N. (2003), "Endogeneity of Currency Areas and Trade Blocs: Evidence from the Interwar Period", Humboldt University, April.

Shepherd, H.L. (1936), The Monetary Experience of Belgium, 1914-1936, Princeton University Press, Princeton.

Shirer, W. L. (1969), The Collapse of the Third Republic: An Inquiry into the Fall of France in 1940, Simon and Schuster, New York.

Wright, J., 2000. Alternative variance-ratio tests using ranks and signs, Journal of Business and Economics Statistics 18, 1-9. 